\title{
Identification of Isolated and in situ Freshwater Sponge Spicules of Eastern Tennessee
}

\author{
Stan C. Kunigelis ${ }^{1}$ and John E. Copeland ${ }^{2}$ \\ 1. DeBusk College of Ostopathic Medicine and \\ 2. Department of Biology Lincoln Memorial University Harrogate, TN 37752
}

Of the 9K known species of sponges, less than 300 are freshwater (FW) and fewer than 35 are known from North America. Last surveyed in 1943 in Tennessee [1], only 4 species of freshwater sponges were identified, all form the Reelfoot Lake region of northwestern Tennessee.

Sponges contain skeletal elements called spicules. Spicules of freshwater sponges are siliceous. Three forms of spicules, megascleres, microscleres and gemmoscleres, are recognized. Spicule shapes and sizes are quite varied and their use for differentiating species is well established [2]. Asexual reproductive resting stages known as gemmules are produced in response to adverse environmental conditions. The protective surface layer of a gemmule is composed of gemmoscleres. Of the three spicule types gemmoscleres are the most importance taxonomically.

The following rivers of eastern Tennessee were surveyed: Clinch, Conasauga, Hiwassee, Holston, Nolichucky, and Powell for the presence of freshwater sponges. Sponges were collected by viewing the undersurfaces of rocks, logs and other submersed structures. Once found, a sponge was viewed using a 10X head loop magnifier for the presence of gemmules. If gemmules were present a small section of sponge was excised and stored in vials containing 70\% ethanol. Each sponge was photographed, given an identification number and located by GPS. In the lab, soft sponge tissues were digested using sodium hypochlorite or nitric acid to release siliceous spicules. Spicules were viewed and photographed using a LEO 982 field emission scanning electron microscope. Additional photos and all measurements were taken using a Hitachi TM 3000 SEM. Spicule chemical composition was determined using a Bruker 70 X-ray elemental analysis system. Freshwater sponges were identified to species using the 2010 key of Reiswig, Frost, and Ricciardi [3].

In 1943, Hoff [1] reported the following species from the Reelfoot Lake region of Tennessee: Eunapius fragilis, Heteromeyenia tubisperma, Racekiela ryderi, and Radiospongilla crateriformis. Since the Appalachian Mountains are now recognized for their biological and ecological diversity, eastern Tennessee streams have been surveyed. To date, we have identified the following species: Ephydatia fluviatilis (Fig. 1c), Eunapius fragilis, Racekiela ryderi, Radiospongilla cerebellata (Fig. 1a), Spongilla lacustris and Trochospongilla horrida (Fig. 1b). Our findings add three additional species to the known sponges of Tennessee. Additional specimens are to be processed from the eastern portion of the state. Further field work is necessary to complete the state-wide survey of Tennessee's freshwater sponges. During the summer of 2014 selected rivers and streams of middle and western Tennessee will be survey.

Freeze cracking of gemmules to elucidate the arrangement of their gemmosclere lattice is under investigation. 
Very little is known of the freshwater sponge fauna of Tennessee. Our findings, concerning species and their distribution, will facilitate a better understanding of this unique group of freshwater invertebrates in Tennessee.

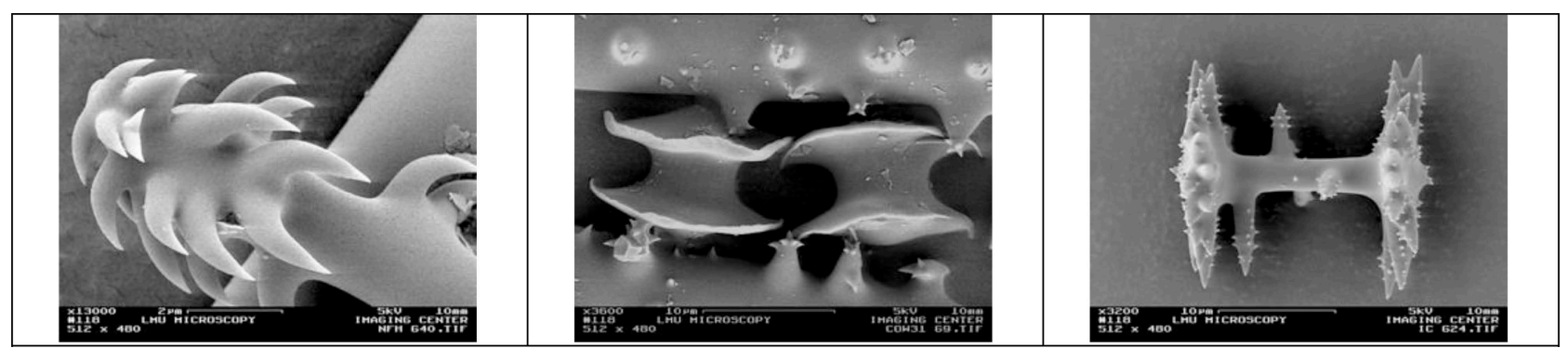

Fig. 1a-c. Diversity of gemnoscleres from freshwater sponges; a) Radiospongilla cerebellata, b) Trochospongilla horrida, c) Ephydatiafluviatilis.

[1] Hoff, C.C. 1943. Some records of sponges, branchiobdellids, and molluscs from the Reelfoot Lake region. TN Acad. of Sci. 18:223-227.

[2] Boury-Esnault, N., K. Rutzler. 1997. Thesaurus of sponge morphology, Smithsonian Contributions to Zoology Number 596, Smithsonian Institution Press, Washington, DC.

[3] Reiswig, H.M., T.M. Frost and A. Ricciardi. 2010. Chapter 4: Porifera, in: J.H. Thorp and A.P. Covich, Eds., Ecology and classification of North American freshwater invertebrates, Academic Press, New York, NY, pp. 91-123. 